\title{
APLIKASI KITOSAN DENGAN PENAMBAHAN EKSTRAK BAWANG PUTIH SEBAGAI PENGAWET DAN PELAPIS EDIBEL BAKSO SAPI (Chitosan Application with Addition of Garlic Extract as a Preservative and Meatballs Edibel Coating
}

Hana N. S. Sri Hadi,Nugraha E. Suyatma*, Rizal Syarief

Departemen Ilmu dan Teknologi Pangan, Institut Pertanian Bogor

Kampus IPB Darmaga Po. Box. 122, BOGOR, 16680

*) Corresponding author: nugrahaedhi@yahoo.com, nugrahaedhi@ipb.ac.id

Diterima/disetujui : 22 Maret 2014/ 9 April 2014

\begin{abstract}
The main objective of this research was to to prolong the shelf life of beef meatball by using chitosan with the addition of garlic extract. Two methods of application, i.e. as preservative agent by mixing chitosan with meatball ingredients and as coating of meatball have been conducted. Prior to application, antimicrobial activities of chitosan and chitosan enriched with garlic extract were assessed by diffusion agar methods. It showed that chitosan solution of $1 \%(\mathrm{w} / \mathrm{V})$ enriched with garlic extract $2 \%(\mathrm{v} / \mathrm{V})$ could inhibit Pseudomonas aureginosa and Bacillus cereus. The application of chitosan enriched with garlic extract as preservative agent could extend the shelf-life of meatball only for 12 hours while its application as edible coating could extend the shelf life of beef meatball until 24 hours when stored at room temperature. This result revealed that the application of chitosan with garlic extract as edible coating were more effective in controlling microbiological growth in meatball than as preservative agent. The micrograph obtained by SEM showed that the surfaces of meatball coated with chitosan were more smooth and compact than those of meatball without coatings.
\end{abstract}

Keywords: chitosan, antimicrobial film, preservative, meatball, edible coating

\section{PENDAHULUAN}

Produk bakso daging sapi memiliki umur simpan yang singkat yaitu kurang dari 8 jam di suhu ruang. Untuk mengatasi hal ini, produsen/pedagang bakso sering mengambil jalan pintas dengan menambahkan bahan berbahaya seperti boraks dan formalin untuk mengawetkan bakso. Berdasarkan hasil survei yang dilakukan Harjanto (2000) di salah satu industri bakso dengan kapasitas 200.000 butir bakso per hari diketahui adanya penambahan formalin pada saat perebusan. Kasus terkini, BPOM Aceh menemukan banyak bakso yang dijual di Pasar Mealaboh (Aceh Barat) mengandung formalin (Harian Serambi Indonesia, Kamis, 18 Juli 2013).

Pemanfaatan kitosan sebagai bahan pengawet alami dapat menjadi salah satu alternatif untuk meningkatkan mutu produk bakso tanpa adannya kekhawatiran pada kesehatan. Kitosan merupakan produk dari deasetilasi kitin dimana kitin merupakan biopolimer alami kedua terbanyak di alam setelah selulosa dan banyak terdapat pada kulit atau cangkang crutacea seperti udang atau kepiting. Kitosan memiliki efek bakterisidal untuk bakteri gram positif seperti Listeria monocytogenes, Bacillus megaterium, B. cereus, Staphylococcus aureus, Lactobacillus plantarum, L. brevis, and L. bulgaris) maupun bakteri Gram negatif seperti E. coli, Pseudomonas fluorescens, Salmonella typhymurium, dan Vibrio parahaemolyticus (No et al., 2002; Cruz-Romero et al., 2013; Shahidi et al., 1999). 
Aplikasi kitosan sebagai pengawet pangan telah banyak diteliti antara lain sebagai pelapis edibel (edible coating) pada produk buah dan sayuran (Jianglian dan Shaoying, 2013; Durango et al., 2004; Dong et al., 2003), pangan olahan seperti keju (Altieri 2005), pizza (Rodriguez et al., 2003), serta produk daging segar (Dehnad et al., 2014) dan daging olahan seperti bologna dan ham (Ouattara 2000).

Dalam penelitian ini dilakukan penambahan ekstrak bawang putih pada kitosan untuk menambah efektivitas kitosan dalam menghambat pertumbuhan mikroba. Elsom et al. (2003) telah membuktikan bahwa ekstrak bawang putih dapat menghambat pertumbuhan $E$. coli. Aktivitas antibakteri bawang putih disebabkan oleh kandungan dialil thiosulfinat yang biasa disebut allisin. Pranoto et al. (2004) menyebutkan komponen senyawa dari bawang putih tidak memberikan pengaruh terhadap sifat fisik pada edible film atau edible coating kitosan karena tidak adanya interaksi antara senyawa bawang putih dengan gugus fungsional kitosan.

Penelitian ini bertujuan untuk mempelajari pengaruh kitosan dengan penambahan ekstrak bawang putih sebagai pengawet alami produk bakso. Secara khusus, penelitian ini ingin membandingkan perbedaan cara aplikasi kitosan dan ekstrak bawang putih untuk pengawetan bakso yaitu sebagai bahan pengawetyang dicampurkan pada adonan bahan pembuatan bakso dan sebagai pelapis edibel yaitu dengan mencelupkan bakso yang sudah jadi (tercetak) kedalam larutan kitosan dan ekstrak bawang putih.

\section{Bahan dan Alat}

\section{METODOLOGI}

Bahan yang digunakan antara lain kitosan komersil, ekstrak bawang putih, bakteri uji (Bacillus cereus dan Pseudomonas fluorescens). Media agar LB dan media agar $\mathrm{NA}, \mathrm{K}_{2} \mathrm{SO}_{4}, \mathrm{HgO}, \mathrm{H}_{2} \mathrm{SO}_{4}$ pekat, $\mathrm{NaOH}$ pekat, $\mathrm{H}_{3} \mathrm{PO}_{3}, \mathrm{HCl} \mathrm{0,02} \mathrm{N}$. Alat yang digunakan antara lainpH meter, labu Kjeldahl $100 \mathrm{ml}$, cawan petri, oven, Texture Analyzer TA-XT2i, micro-cal Messmer, Scanning Electron Microscopy 5310LV (JEOL).

\section{Karakterisasi Kitosan (derajat deasetilasi kitosan).}

Perhitungan derajat deasetilasi menggunakan spektrum Faurier Transform Infrared (FTIR) dengan membandingkan absorbansi panjang gelombang $1655 \mathrm{~cm}^{-1}$ dan absorbansi pada panjang gelombang $3450 \mathrm{~cm}^{-1}$ (Baxter et al., 1992).

Pengujian antimikroba kitosan dan ekstrak bawang putih menggunakan metode difusi sumur agar (Carson and Riley, 1995).

Kultur dengan jumlah bakteri $10^{5} \mathrm{CFU} / \mathrm{ml}$ sebanyak $1 \mathrm{ml}$ dimasukkan kedalam cawan perti dan dituangkan media agar sebanyak $20 \mathrm{ml}$, dibiarkan membeku lalu dibuat sumur dengan diameter $8 \mathrm{~mm}$. Sampel antibakteri dimasukkan kedalam sumur, diinkubasi $37^{\circ} \mathrm{C}$ dan diamati zona bening yang terbentuk selama 20 jam. Air destilata steril digunakan sebagai kontrol.

\section{Pengujian Edible Coating dengan Scanning Electron Microscopy (SEM) (Lin et al., 2002).}

Pengukuran Scanning Electron Microscopy (SEM) dilakukan untuk melihat mikrostruktur edible coating. Analisis SEM menggunakan alat SEM 5200 (JEOL). Bakso yang telah dilapisi edible coating kitosan sebelumnya dikeringkan dengan freeze dryer selama 19 jam sampai kadar air $\pm 2 \%$, kemudian dipotong dengan ukuran $0,5 \times 0,5 \mathrm{~cm}^{2}$. Setelah preparasi selesai dilakukan pelapis menggunakan emas ( $\mathrm{Au}$ ) didalam Magnetron Sputtering Device yang dilengkapi dengan pompa vakum. Selanjutnya sampel yang telah 
dilapisi diletakan pada lokasi sampel dalam mikroskop elektron dan dengan terjadinya tembakan elektron kearah sampel, maka akan terekam ke dalam monitor dan dilakukan pemotretan.

\section{Penentuan sifat fisik, kimia dan organoleptik pada produk bakso.}

Sifat fisik dan kimia produk bakso meliputi pengukuran pH (AOAC, 1999), kadar protein (AOAC, 1999), kadar air (AOAC, 1999), kadar lemak (AOAC, 1999), penentuan tekstur (kekerasan) diukur dengan Texture Analyzer TA-XT2i menggunakan probe compress, pengukuran aktivitas air (aw) dengan aw meter (Shibaura, USA), analisis total mikroba (Fardiaz, 1989), analisis warna dilakukan dengan notasi warna Hunter L, a,b dengan Chromameter (Minolta CR200) dan uji organoleptik (Soekarto, 1985).

\section{HASIL DAN PEMBAHASAN}

\section{Karakteristik kitosan}

Hasil pengujian karakteristik kitosan komersil yang digunakan pada penelitian ini dapat dilihat pada Tabel 1.

Tabel 1. Karakteristik kitosan komersil

\begin{tabular}{lll}
\hline Karakteristik & Hasil penelitian & $\begin{array}{l}\text { Standar mutu kitosan } \\
\text { (Protan Laboratories) }^{*}\end{array}$ \\
\hline Bentuk Partikel & Serbuk & Serpihan atau bubuk \\
Kadar Air & $12 \%$ & $\leq 10 \%$ \\
Kadar Abu & $0.4 \%$ & $\leq 2 \%$ \\
Kadar Nitrogen & $6 \%$ & $\leq 5 \%$ \\
Derajat Deasetilasi & $80 \%$ & $\geq 70 \%$ \\
\hline
\end{tabular}

${ }^{*}$ Sumber: Suptijah et al. (1992)

Derajat deasetilasi kitosan ditentukan dengan analisis FTIR, sebesar $80 \%$ berdasarkan hasil analisis dengan spektroskopi FTIR (Gambar 1). Derajat deasetilasi menunjukkan kemurnian kitosan dan menentukan banyaknya gugus asetil yang hilang selama proses deasetilasi kitin. Semakin besar derajat deasetilasi, maka kitosan akan semakin aktif. Keaktifan kitosan dikarenakan banyaknya gugus amina menggantikan gugus asetil, gugus amina lebih reaktif dibandingkan gugus asetil karena adanya pasangan elektron bebas pada atom nitrogen dalam struktur kitosan.

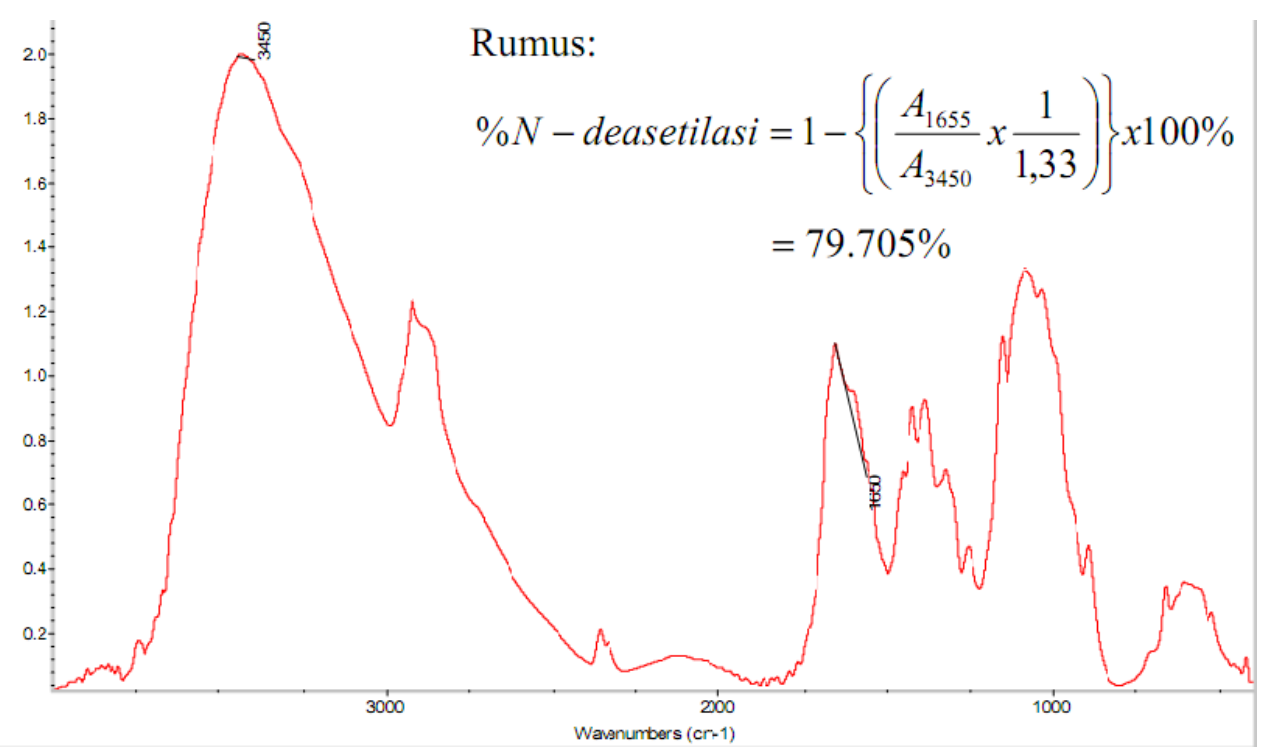




\section{Gambar 1. Spectra FTIR kitosan dan cara perhitungan derajat deasetilasinya}

Karakteristik dari kitosan komersil telah memenuhi standar yang telah ditetapkan diantaranya warna larutan, kadar abu dan bentuk pertikel. Karakteristik kitosan lainnya yang belum memenuhi standar adalah kadar air dan kadar nitrogen. Kadar nitrogen yang belum memenuhi standar dipengaruhi pada saat proses deproteinasi. Kadar air yang tinggi pada sampel ini dipengaruhi penyimpanan dan kemasan yang kurang baik, karena sifat kitosan yang higroskopis. Walaupun kedua karakteristik tersebut belum memenuhi standar yang ditetapkan, diduga tidak akan mempengaruhi fungsinya sebagai edible coating, karena dalam aplikasinya kitosan tersebut diencerkan dengan air.

\section{Uji antimikroba kitosan dan kombinasi dengan ekstrak bawang putih}

Kitosan memiliki sifat tidak larut dalam air tetapi larut dalam larutan asam dengan $\mathrm{pH} \leq 6$ dan asam organik seperti asam asetat, asam format dan asam laktat. Pada pengujian ini kitosan divariasikan dengan konsentrasi yaitu $1 \%$ dan $2 \%(\mathrm{~b} / \mathrm{v})$ dalam larutan asam laktat $2 \%$,sedangkan untuk penambahan ekstrak divariasikan dengan konsentrasi $2 \%, 4 \%, 6 \% \quad(\mathrm{v} / \mathrm{v})$. Pengujian aktivitas antimikroba bertujuan untuk membuktikan apakah kitosan dan penambahan ekstrak bawang putih mampu meningkatkan daya antimikroba. Hasil penelitian menunjukan bahwa aktivitas pertumbuhan bakteri pada 8 kombinasi larutan kitosan dan ekstrak terhadap bakteri uji memperlihatkan zona penghambat yang bervariasi (Tabel 2).

Tabel 2. Diameter zona penghambatan bakteri

\begin{tabular}{lcc}
\hline Sampel & \multicolumn{2}{c}{ Diameter zona penghambatan $(\mathrm{mm})$} \\
\hline Kitosan 1\% & Pseudomonas aureginosa & Bacillus cereus \\
Kitosan 1\% + ekstrak 2\% & $\mathbf{7 , 4 2}^{\mathrm{dc}}$ & $\mathbf{7 , 6 3 ^ { \mathrm { b } }}$ \\
Kitosan 1\% + ekstrak 4\% & $\mathbf{8 , 9 3}^{\mathrm{a}}$ & $\mathbf{8 , 7 0 ^ { \mathrm { a } }}$ \\
Kitosan 1\% + ekstrak 6\% & $7,95^{\mathrm{bc}}$ & $8,17^{\mathrm{ab}}$ \\
\hline Kitosan 2\% & $8,17^{\mathrm{b}}$ & $7,80^{\mathrm{ab}}$ \\
Kitosan 2\% + ekstrak 2\% & $\mathbf{6 , 6 3 ^ { \mathrm { dc } }}$ & $\mathbf{6 , 2 7 ^ { \mathrm { c } }}$ \\
Kitosan 2\% + ekstrak 4\% & $\mathbf{6 , 7 8 ^ { \mathrm { dc } }}$ & $\mathbf{6 , 1 5 ^ { \mathrm { c } }}$ \\
Kitosan 2\% + ekstrak 6\% & $5,48^{\mathrm{e}}$ & $5,97^{\mathrm{c}}$ \\
\hline
\end{tabular}

Angka-angka dalam kolom yang sama dan diikuti huruf superskrip berbeda $(a, b, c, d, e)$ menunjukkan berbeda nyata $p<0,05$.

Tabel 2 memperlihatkan bahwa perlakuan (kitosan dan ekstrak) memberikan perbedaan yang nyata pada penghambatan Pseudomonas aureginosadan Bacillus cereuspada taraf kepercayaan 0,05 . Berdasarkan hasil pengukuran uji lanjut Duncan pada kedua bakteri tersebut terlihat bahwa kitosan $1 \%$ dan kitosan $2 \%$ berbeda nyata pada taraf 0,05 . Hasil tersebut menunjukkan bahwa kitosan $1 \%$ memiliki diameter penghambatan lebih besar dibandingkan kitosan $2 \%$ sebesar 7,42 mm dan 7,63 mm. Hal ini membuktikan bahwa larutan kitosan $1 \%$ mampu menghambat pertumbuhan kedua mikroba uji.

Hasil uji Duncan untuk kitosan (1\%) dengan penambahan ekstrak bawang putih dengan kitosan $1 \%$ tanpa ekstrak memperlihatkan perbedaan yang nyata pada taraf 0,05 dimana kitosan $1 \%$ memiliki diameter penghambatan sebesar $8,93 \mathrm{~mm}$ ( $P$. aureginosa) dan $8,70 \mathrm{~mm}$ (B.cereus). Nilai penghambatan ini lebih besar dibandingkan dengan kitosan 2\% berdiameter sebesar $6,78 \mathrm{~mm}$ ( $P$. aureginosa) dan 6,15 mm (B.cereus)(Gambar 2). Semakin besar diameter daerah penghambatan menunjukkan 
semakin efektif bahan antimikroba dalam menghambat pertumbuhan bakteri. Penambahan antimikroba ekstrak bawang putih pada kitosan $1 \%$ memperlihatkan peningkatan diameter penghambatan pada kedua bakteri uji, dibandingkan hanya menggunakan satu jenis bahan antimikroba (larutan kitosan saja). Mehrabian (1992) melaporkan bahwa ekstrak bawang putih dengan uji difusi agar, mampu menghambat 7 macam bakteri patogen yaitu E.coli, S. typhimurium, S. havana, S. para, A. flexneri dan Shigella dysentriae. Miron et al. (2000) menyatakan bahwa alisin memiliki permeabilitas yang tinggi dalam menembus membran fospolipid dinding sel bakteri. Gugus thiol pada allisin kemudian akan bereaksi dengan enzim-enzim yang mengandung sulfurhidril yang menyusun membran sel, hal ini diduga menyebabkan struktur dinding sel bakteri mengalami lisis. Didukung dengan penelitian yang dilakukan oleh Bakri (2005) menyatakan bahwa bakteri Gram negatif lebih sensitif dibandingkan bakteri Gram positif terhadap bawang putih khususnya senyawa allisin. Aplikasi kitosan dan bawang putih sebagai edible film menunjukkan tidak adanya perubahan pada sifat mekanik dan fisik edible film yang dihasilkan.

Diameter penghambatan bakteri pada kitosan 1\% dan penambahan ekstrak menunjukan Pseudomonas aeruginosa (Gram negatif) lebih sensitif dibandingkan Bacillus cereus (Gram positif). Hal ini dikarenakan kitosan yang dilarutkan pada larutan asam memiliki gugus amino bebas kemudian akan terprotonasi membentuk polikationik. Polikationik ini menunjukkan kerapatan muatan yang tinggi yang bersifat polielektrolit kationik yang sangat efektif berinteraksi dengan biomolekul bermuatan negatif dan biomolekul permukaan seperti permukaan sel bakteri yang bermuatan negatif, dimana bakteri Gram negatif mempunyai sisi hidrofilik, yaitu karboksil, asam amino dan hidroksil.

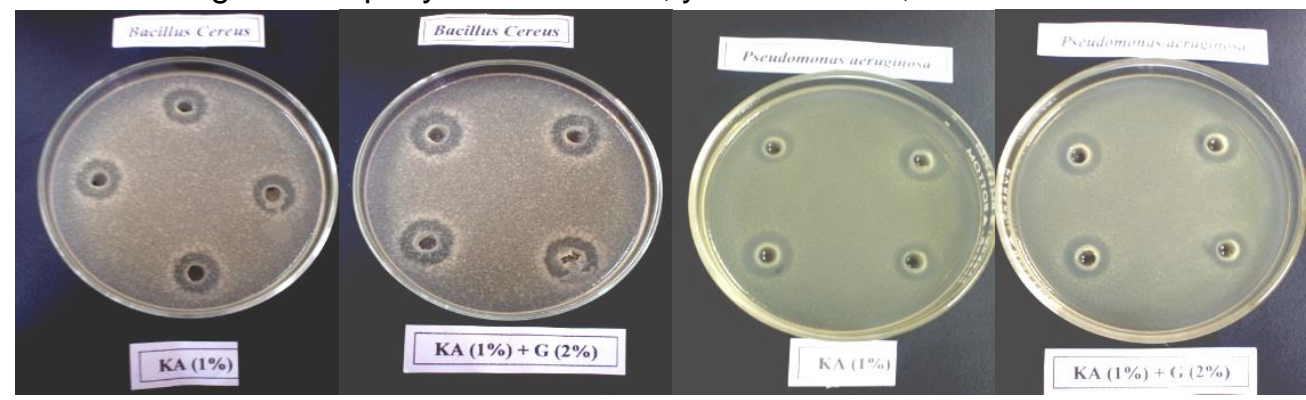

(a)

(b)

Gambar 2. Zona penghambatan antibakteri kitosan 1\% dan kitosan $1 \%$ dengan penambahan ekstrak $2 \%$ pada bakteri $B$. cereus (a)dan $P$. aureginosa (b)

Penambahan ekstrak bawang putih $2 \%$ dalam larutan kitosan $1 \%$ kemudian diaplikasikan sebagai bahan tambahan dalam produk adonan bakso dan edible coatingbakso. Konsentrasi yang digunakan pada campuran adonan bakso adalah kitosan $1 \%(A K)$ dan kitosan 1\% dengan penambahan ekstrak bawang putih $2 \%$ (AKG). Konsentrasi yang dibutuhkan sebagai edible coating yaitu kitosan $1 \%(\mathrm{CK})$ dan kitosan $1 \%$ dengan penambahan ekstrak bawang putih $2 \%$ (CKG).

\section{Aplikasi kitosan pada adonan dan edible coating bakso}

\section{Aktifitas air (water aktivityl $\mathrm{a}_{\mathrm{w}}$ )}

Nilai $a_{w}$ pada produk bakso dengan kitosan sebagai bahan pengawet (AK dan AKG) menunjukkan peningkatan selama penyimpanan. Nilai $a_{w}$ yang diperoleh pada jam ke-0 masing-masing berkisar 0,861-0,837 dan meningkat pada jam ke-24 antara 0,9290,949 . Nilai aw pada jam ke-24 telah mencapai lebih dari 0,90, dimana nilai tersebut merupakan batas pertumbuhan bakteri. Dengan demikian dapat diduga bahwa 
kerusakan produk bakso mulai terjadi pada jam ke-24 (Gambar 3a), sedangkan untuk produk bakso yang dilapisi kitosan dengan dan tanpa garlic extract (CK dan CKG) memiliki nilai aw yang relatif stabil. Hal ini diduga karena lapisan kitosan mampu mempertahankan $a_{w}$ produk. Peningkatan aw pada jam ke-0 meningkat secara perlahan sampai jam ke-36, dan terlihat cenderung stabil pada jam ke-12 sampai jam ke-36. Pada kontrol peningkatan nilai $a_{w}$ cenderung meningkat dengan cepat.

Peningkatan nilai $a_{w}$ pada edible coating bakso terjadi secara perlahan, dimana nilai $a_{w}$ terendah dapat menghambat pertumbuhan kapang dan seiring dengan meningkatnya aw maka pertumbuhan bakteri juga akan meningkat (Gambar 3b). Fungsi dari edible coating pada pengujian ini yaitu menahan uap air masuk kedalam bahan sehingga keawetan produk dapat dipertahankan, dengan demikian membuktikan bahwa edible coating (CK dan $\mathrm{CKG}$ ) mampu mempertahankan aw produk dibandingkan dengan produk (AK dan AKG).

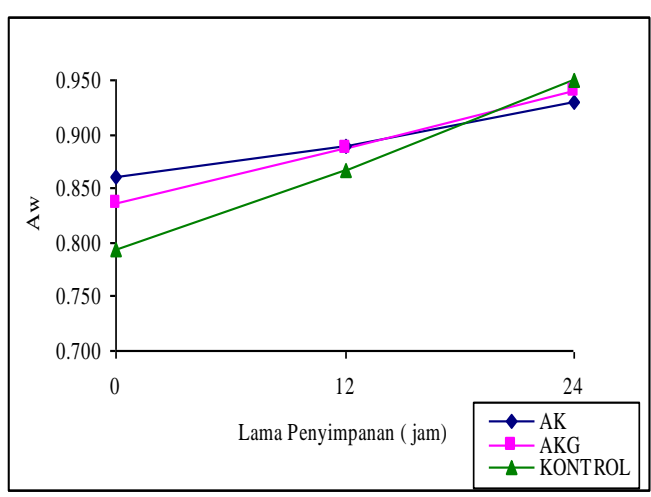

(a)

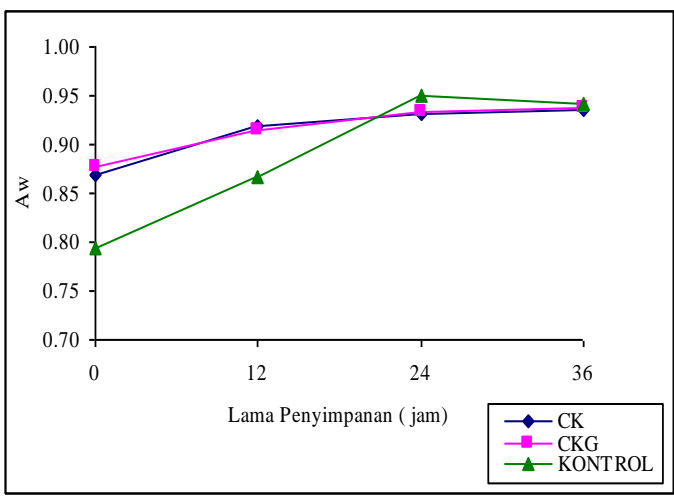

(b)

Gambar 3. Perubahan nilai awselama penyimpanan (a)24 jam dan (b)36 jam

\section{Nilai pH}

Nilai $\mathrm{pH}$ pada produk $\mathrm{AK}, \mathrm{AKG}$ dan kontrol jam ke-0 masih relatif tinggi, $\mathrm{pH}$ bakso kemudian mengalami penurunan pada jam ke-12 sampai jam ke-24, Penurunan yang sangat rendah yaitu pada kontrol $(\mathrm{pH} 5,53)$, dibandingkan dengan $\mathrm{AK}(\mathrm{pH} 6,09)$ dan AKG (pH 6,24). Penurunan $\mathrm{pH}$ pada produk AK dan AKG tidak menurun secara drastis. Hal ini dikarenakan adanya kitosan dan ekstrak bawang putih yang membantu untuk mempertahankan $\mathrm{pH}$ bakso dan menghambat pertumbuhan bakteri asam laktat (Gambar 4a). Adam dan Moss (1995) menyatakan bahwa secara umum bakteri tumbuh lebih cepat pada $\mathrm{pH}$ 6,0-8,0; sedangkan khamir pada 4,5-6,0 dan kapang pada $\mathrm{pH} 3,5-4,0$ pengecualian pada bakteri yang memproduksi asam sebagai hasil metabolismenya. Produk CK dan CKG memperlihatkan pengaruh lama penyimpanan jam ke-0 sampai jam ke-24 terjadi peningkatan $\mathrm{pH}$ yang kecil dan cenderung stabil dibandingkan dengan kontrol (Gambar 4b). Kondisi selanjutnya (jam ke-24) adalah stasioner atau dapat dikatakan $\mathrm{pH}$ produk dapat dipertahankan seminimal mungkin, yang diduga pengaruh adanya edible coating. Pelapisan bakso kitosan dan kitosan dengan ekstrak dapat menghambat penurunan $\mathrm{pH}$, karena semakin rendah $\mathrm{pH}$ dapat meningkatkan jumlah asam laktat. Bakteri asam laktat dan Lactobacilli yang tumbuh pada $\mathrm{pH}$ antara 5,0-6,0. Namun kondisi tersebut berubah pada jam ke-36, nilai pH mulai menurun membuktikan bahwa mulai terjadi pertumbuhan bakteri yang menimbulkan keasaman produk. 


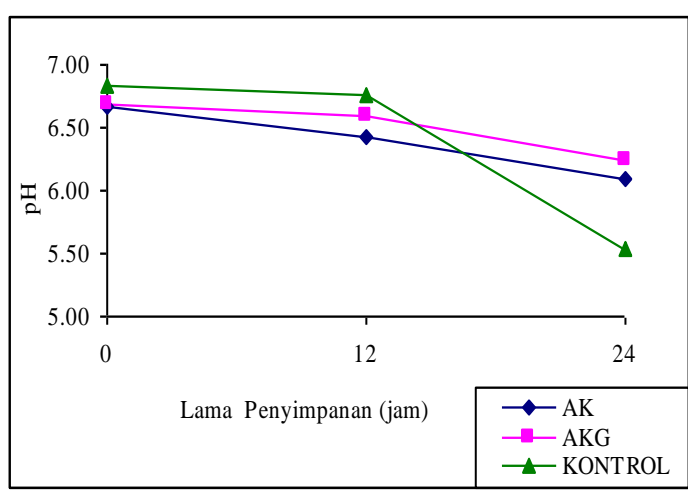

(a)

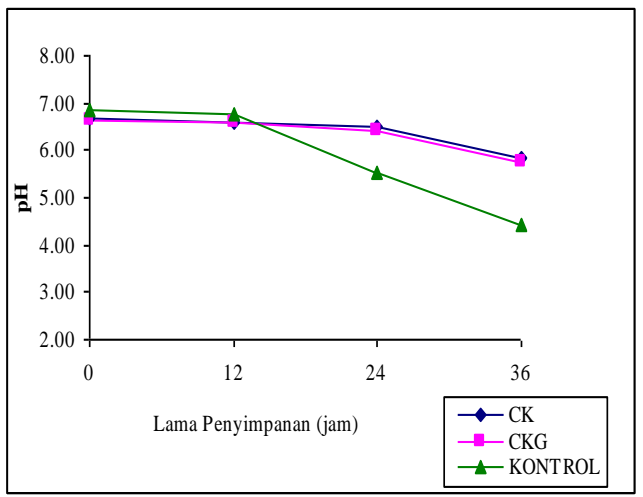

(b)

Gambar 4. Nilai pH bakso selama penyimpanan (a) 24 jam dan (b) 36 jam

\section{Nilai kekerasan}

Produk AK dan AKG menunjukan nilai kekerasan berkisar 8,36 N dan 8,42 N sedangkan untuk kontrol tanpa penambahan kitosan maupun ekstrak menghasilkan nilai yang rendah yaitu $7.58 \mathrm{~N}$ (Gambar 5a).Penambahan kitosan sebesar 1\% dapat mempengaruhi kekerasan, hal ini disebabkan karena kitosan memiliki kapasitas pembentuk gel sehingga penambahannya pada adonan bakso akan dapat meningkatkan kekuatan gel pada produk akhir. Kitosan dapat digunakan sebagai pengental atau pembentuk gel yang sangat baik, pengikat, penstabil dan pembentuk tekstur (Chang et al., 2003). Penurunan nilai kekerasan jam ke-24 pada kontrol disebabkan tidak adanya zat antimikroba pada bakso sehingga mikroba memasuki fase logaritmik dan mulai mendekomposisi komponen organik, yang menimbulkan kebusukan dan tekstur yang lunak.

Hasil yang pengukuran nilai kekerasan pada produk (CK, CKG) dengan produk (AK, AKG) pada rentang waktu 12 jam memberikan nilai yang berbeda. Produk CK dan CKG memperlihatkan penurunan nilai kekerasan produk dapat diminimalkan (Gambar $5 b)$. Pengaruh penambahan ekstrak memperlihatkan penurunan nilai yang berbeda dengan produk $\mathrm{CK}$, hal tersebut memperlihatkan bahwa produk CKG dapat menghambat kerusakan tekstur secara perlahan. Semakin rendah nilai kekerasan menunjukan tekstur produk semakin lunak. Aplikasi edible coating memberikan gambaran bahwa pelapisan kitosan dengan penambahan ekstrak membantu menjaga produk dari kerusakan sehingga mempertahankan kekerasan produk.

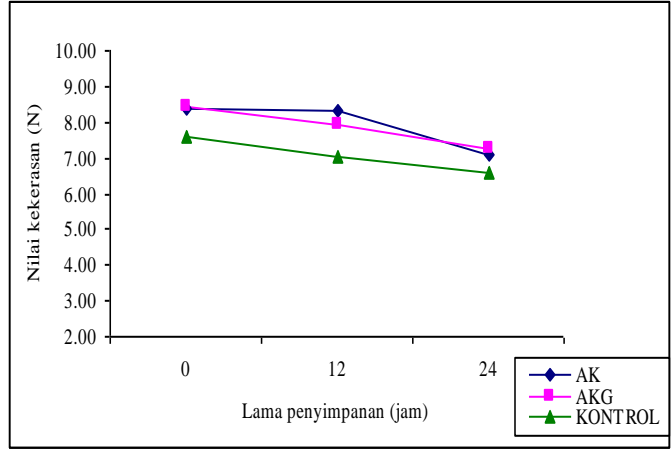

(a)

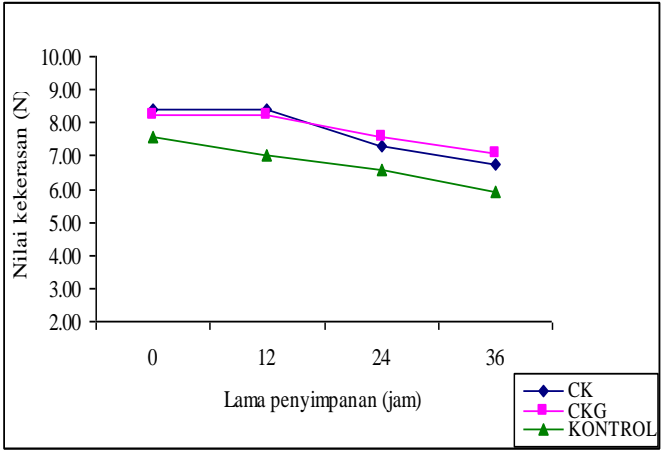

(b)

Gambar 5. Nilai kekerasan bakso selama penyimpanan (a) 24 jam dan (b) 36 jam 


\section{Nilai Total Plate Count (TPC)}

Nilai TPC dari produk AK dan AKG dapat dikatakan bahwa jumlah mikroorganisme cenderung semakin meningkat dengan lamanya penyimpanan (Gambar 6a). Pada jam ke-0 nilai TPC telah memenuhi standar SNI 01-3818-1995 (1×103 koloni/g). Keadaan selanjutnya memperlihatkan pertumbuhan bakteri mulai meningkat, pada lama

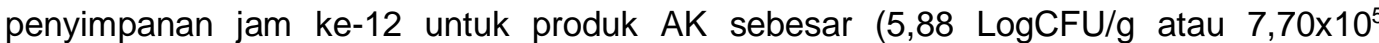
koloni/g) dan AKG (5,28 LogCFU/g atau $\left.3,87 \times 10^{5} \mathrm{koloni} / \mathrm{g}\right)$. Keduanya memiliki jumlah

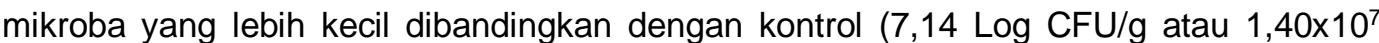
unit koloni/g, kondisi ini diduga akibat penambahan kitosan dan ekstrak yang menghambat pertumbuhan bakteri. Namun kondisi tersebut cepat berubah dan terjadi peningkatan sejalan dengan lama penyimpanan pada jam ke-24. Penilaian yang berbeda dari hasil analisis TPC produk CK dan CKG dengan edible coating pada awal penyimpanan jam ke-0 sampai jam ke-12 belum memperlihatkan adanya pertumbuhan bakteri pada kedua produk (Gambar $6 \mathrm{~b}$ ) dibandingkan dengan kontrol maupun produk AK dan AKG. Kondisi ini dipengaruhi adanya pelapis yang mampu melindungi bakso dari kontaminasi mikroba khususnya pada permukaan bahan pangan. Jumlah bakteri pada jam ke-0 sampai jam ke-12 masih sesuai dengan standar SNI. Peningkatan jumlah

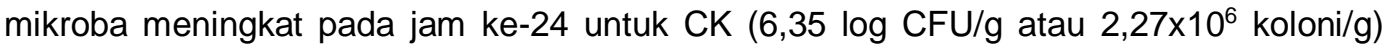

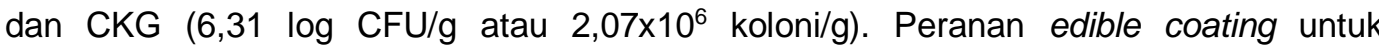
mencegah pertumbuhan mikroba dapat diminimalkan dengan menghambat pertumbuhan mikroba yang dimulai pada permukaan produk, dimana permukaan produk atau lapisan luar produk merupakan substrat utama pertumbuhan mikroba.

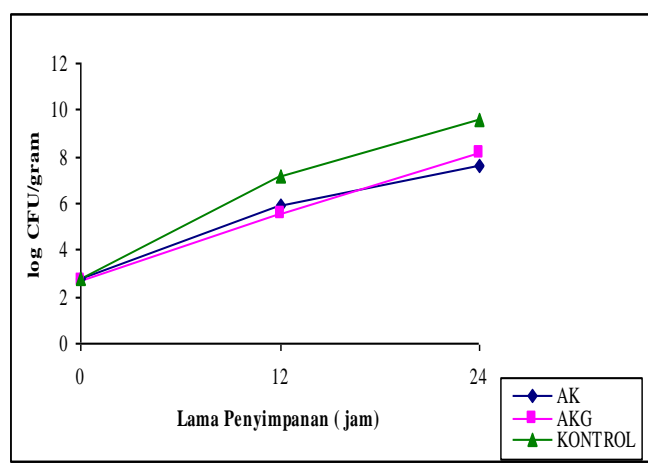

(a)

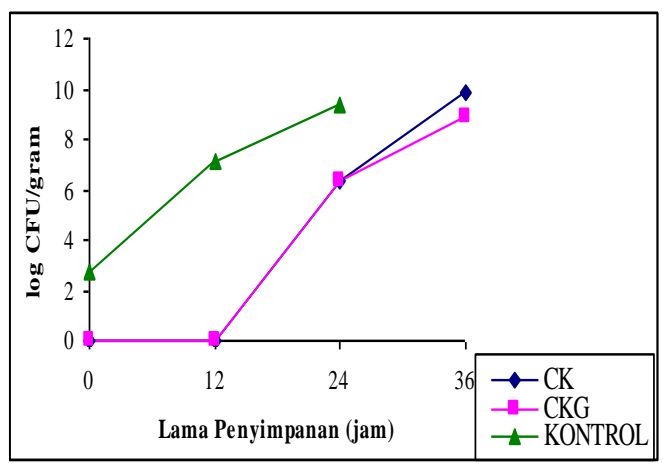

(b)

\section{Organoleptik}

Gambar 6. Nilai TPC bakso selama penyimpanan (a) 24 jam dan (b) 36 jam

Nilai organoleptik menunjukkan tingkat kesukaan yang tidak berbeda nyata $(p>0,05)$ antara produk AK, AKG, CK dan CKG. Berdasarkan tingkat kesukaan (uji hedonik) hasil penilaian atribut kesukaan menunjukkan bahwa kitosan dengan penambahan ekstrak bawang putih memiliki nilai tertinggi yaitu AKG (Gambar 7a) dan CKG (Gambar 7b).

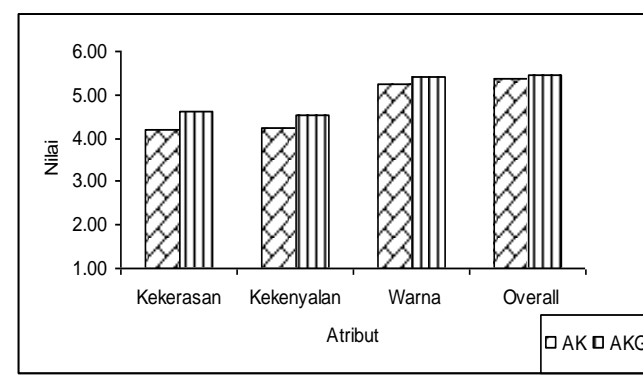

(a)

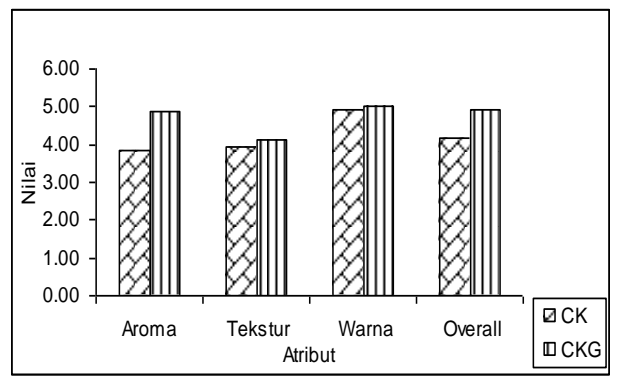

(b)

Gambar 7. Nilai organoleptik produk bakso AK,AKG (a) dan CK,CKG (b) 


\subsubsection{Mikrostruktur edible coating bakso}

Pengamatan mikrostruktur dari edible coating kitosan bertujuan untuk melihat lapisan kitosan yang terbentuk pada bakso yang diamati menggunakan alat SEM (scanning electron microscope). Pengamatan menggunakan SEM memperlihatkan bahwa larutan kitosan mampu melapisi bakso dengan baik. Mikrostruktur bakso dengan pelapis kitosan dengan penampang melintang memperlihatkan adanya perbedaan mikrostruktur. Gambar 8a memperlihatkan adanya pelapisan (edible coating) yang menutupi permukaan produk, sedangkan pada Gambar 8b memperlihatkan struktur bakso tanpa edible coating. Hasil mikrostruktur yang memperlihatkan adanya edible coating menunjukkan bahwa kitosan dapat melapisi bakso dengan baik dan dapat dibuktikan dari data pengujian secara fisik ( $\mathrm{a}_{\mathrm{w}}, \mathrm{pH}$, kekerasan dan TPC) yang memberikan penilaian bahwa edible coating berfungsi sebagai barrier dengan menghambat pertumbuhan mikroba khususnya pada permukaan bahan pangan dan mampu mempertahankan mutu produk jika dibandingkan tanpa adanya edible coating.

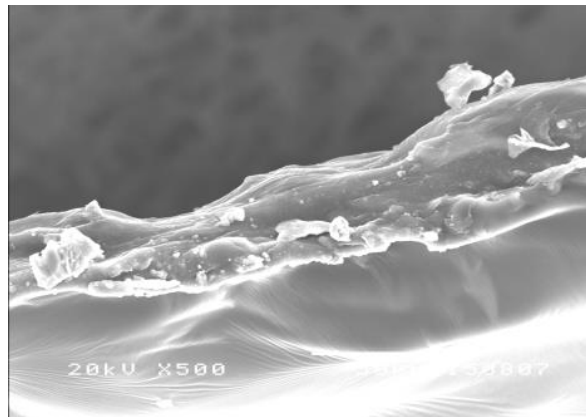

(a)

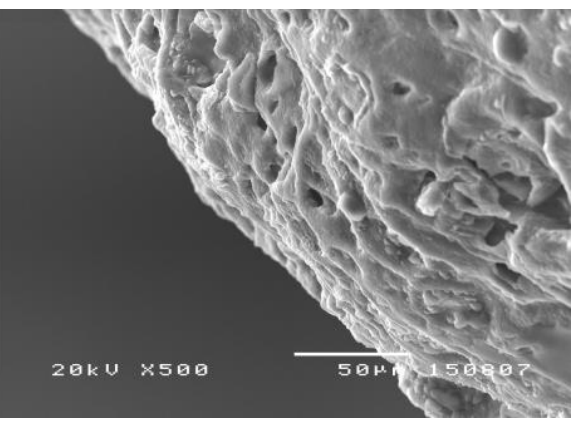

(b)

Gambar 8. Penampang melintang bakso dengan edible coating (a) dan tanpa edible coating $(\mathrm{b})$

\section{SIMPULAN}

Aktivitas antimikroba larutan kitosan 1\% mampu menghambat pertumbuhan Pseudomonas aureuginosa dan Bacillus cereus. Penambahan ekstrak bawang putih $2 \%$ dengan kitosan $1 \%$ mampu meningkatkan penghambatan pertumbuhan mikroba uji dibandingkan hanya menggunakan satu jenis antibakteri (larutan kitosan 1\%). Aplikasi kitosan larutan $1 \%$ dan penambahan ekstrak bawang putih pada adonan bakso meningkatkan umur simpan selama 12 jam, sedangkan aplikasi sebagai edible coating mampu meningkatkan umur simpan selama 24 jam dibandingkan dengan kontrol pada penyimpanan dalam suhu ruang. Pengamatan dengan mengggunakan Scanning Electron Microscopy memperlihatkan adanya perbedaan mikrostruktur antara produk dengan pelapis dimana produk yang dilapisi kitosan memiliki permukaan yang kompak dan mulus dan dapat menghambat pertumbuhan mikroba di permukaan produk pangan. Hasil penelitian ini membuktikan bahwa cara aplikasi kitosan sebagai pelapis edibel lebih efektif dibandingkan aplikasinya sebagai bahan pengawet (dicampurkan dalam adonan bahan).

\section{DAFTAR PUSTAKA}

AOAC. 1999. Oficial Methods of analysis. 15 th Ed. AOAC Inc. Arlington. Virginia, USA. 
Alteri C. C Scrocco, Sinigaglia M, Del Nobile MA. .2005. Use of Chitosan to Prolong Mozzarella Cheese Shelf Life. Journal of Dairy Science, 88, 2683-2688.

Bakri IM, Douglas CD. 2005. Inhibitory effect of garlic extract on oral bacteria. Arch Oral Biology, 50, 645-651.

Baxter A, Dillon M, Taylor KDA, Roberts GAF. 1992. Improved method for i.r. determination of the degree of $\mathrm{N}$-acetylation of chitosan. International Journal Biological Macromolecules, 14,166-169.

Carson CF, Riley TV. 1995. Antimicrobial activity of the Major components of the essential oil of Melalueca alternifolis. Journal of Applied Bacteriology, 78, 264 269.

Chang KLB, LinY.-S., Chen RH. 2003. The effect of chitosan on the gel properties of tofu (soybean curd). Journal of Food Engineering, 57, 315-319.

Cruz-Romero MC, Murphy T, Morris M., Cummins E., Kerry JP. 2013. Antimicrobial activity of chitosan, organic acids and nano-sizedsolubilisates for potential use in smart antimicrobially-activepackaging for potential food applications. Food Control, 34, 393-397.

Dong HL, Cheng JT, Zheng K, Jiang Y. 2003. Effect chitosan coating on quality and shelf life of peeled litchi fruit. Journal of Food Engineering, 64, 355-358

Durango AM. Soares NFF. Andrade NJ. 2004. Microbiological evaluation of an edible antimicrobial coating on minimally processed carrots. Journal of Food Control, 17, 336-341

Elsom GL, Freeman JA, Hide D dan Salmon DM. 2003. Antibacterial and anticandidal effect of aqueous extract of garlic oil on the growth of mixed cultures and the anticandidal and platelet activity of commercial preparation of garlic. Microbial Ecology in Heath and Disease, 15,193-199.

Fardiaz S.1989. Mikrobiologi Pangan. Lembaga sumberdaya Informasi IPB.Bogor.

Harjanto S. 2000. Pengembangan Metode Pengawetan Bakso Daging Sapi pada Penyimpanan Suhu Kamar. Skripsi. Fakultas Teknologi Pangan dan Gizi IPB, Bogor.

Jianglian, D., Shaoying, Z. 2013. Application of Chitosan Based Coating in Fruit and Vegetable Preservation: A Review. Journal of Food Processing and Technology, 4: 227-231.

Lin S, Huff HF, Hsieh F. 2002. Extruction process parameter, sensory characteristics and structural properties of a Hight moisture soy protein meat analog. Journal of Food Science, 67, 1066-1072.

Mehrabian SH, Larry- Yazdy.1992. Antimicrobial Activity of Allium sativum, Allium cepa, Allium porrum, (Liliaceae) Against Enteric Pathogens (Enterobacteriacea) ISHS Acta Holticulturae 319: International Symposium on Transplant Production System

Miron TA, Rabinkov, Mirelman M. Wilchek L, Weiner. 2000. The mode Action of Allicin: Its Ready Permeability Through Phospolipid Membranes May Contribute to Its Biological Activity. Biochemical and Biophysic Acta, 1463, 20-30.

No HK, Park NY, Lee SH, Meyer SP. 2002. Antibacterial activity of chitosan and chitosan oligomer with different molecular weight. International Journal of Food microbiology, 74, 65-72. 
Ouattara B, Simard RE, Piette G, Bégin A, Holley RA. 2000. Inhibition of surface spoilage bacteria in processed meats by application of antimicrobial. International Journal of Food Microbiology. 62:139-48.

Pranoto Y, Salokhe Vilas M, Sudip K. Rakshit.2005. Physical and antibacterial properties of alginate-based edible film incorporated with garlic oil. Food Research International, 38, 267-272.

Rodriguez MS, Ramos V, Anullo E. 2003. Antimicrobial action of chitosan against spoilage organisms in precooked pizza. Journal of Food Science, 68, 271-274.

Shahidi, Arachchi JKV dan.Jeon YJ. 1999. Food Aplication of Chitin and Chitosan. Trend in Food Science and Technology, 10, 37-51.

SNI NO.01-3818-1995. Bakso Daging. Dewan Standardisasi Indonesia, Jakarta

Suptijah P, Salamah E, Sumaryanto H, Purwaningsih S, Santoso J. 1992. Pengaruh berbagai metode isolasi kitin dari kulit udang terhadap kadar dan mutunya. Laporan penelitian Faperikan. IPB.

Soekarto ST. 1985. Penilaian organoleptik. Bina Aksara. Jakarta. 